JURNAL GIZI DAN DIETETIK INDONESIA

Vol. 2, No. 3, September 2014: 159-169

\title{
Pola makan dan pantangan makan tidak berhubungan dengan kekurangan energi kronis pada ibu hamil
}

\author{
Dietary pattern and food taboo did not associate with chronic energy deficiency in pregnant \\ women
}

Oktriyani ${ }^{1}$, Muhammad Juffrie ${ }^{2}$, Dewi Astiti ${ }^{3}$

\begin{abstract}
Background: Chronic energy deficiency (CED) is a chronic malnutrition in calorie and protein that become a nutritional problem in pregnant women. Prevalence of CED in Indonesia in 2013 is $23.4 \%$ and Sedayu Subdistrict is $11.4 \%$. Impact of CED in pregnant women is the risk of low birth weight and its relationship with increase chronic desease in the future. Dietary pattern and food taboo are factor risks of nutritional problem of pregnant women.

Objectives: To analyze association between dietary pattern and food taboo with chronic energy deficiencies in pregnant women in Sedayu Subdistrict, Bantul, Yogyakarta.

Methods: This was an observational study with cross sectional design with approachment in quantitative and qualitative. Qualitative method used focus group disscussion (FGD) with 14 CED and non CED in pregnant women. Samples were 201 pregnant women in Sedayu Subdisctrict that were collected by total sampling methods. This research was held in April until June 2014. Data were analyzed using univariate analysis (descriptive), bivariate (chi-square and Mann Whitney), and multivariate (multiple logistic regression). Intake of energy and carbohydrate was analyzed by using Nutrisurvey software.

Results: Chi-square showed that there was no significant association between dietary pattern and food taboo with CED in pregnant women ( $p>0.05$ ). A number of $17.91 \%$ pregnant women had the risk of CED, $20.99 \%$ had less of source prime energy, and $20.22 \%$ had food taboo. Food taboo is food that rich in protein, vitamin and mineral (fruit and vegetable) and energy.

Conclusions: There was no significant association between dietary pattern and food taboo with CED in pregnant women.
\end{abstract}

KEYWORDS: dietary pattern, food taboos, pregnant women, chronic energy deficiencies

\begin{abstract}
ABSTRAK
Latar belakang: Kekurangan energi kronis (KEK) merupakan keadaan kekurangan zat gizi terutama energi dan protein yang masih menjadi masalah gizi pada ibu hamil. Prevalensi KEK di Indonesia tahun 2013 sebesar 23,4 \% dan Kecamatan Sedayu sebesar 11,4\% masih merupakan masalah kesehatan. Ibu hamil yang KEK berisiko melahirkan bayi dengan berat badan rendah dan meningkatkan risiko penyakit kronis di masa depan. Pola makan dan pantangan makan merupakan salah satu faktor risiko dari masalah gizi ibu hamil.

Tujuan: Mengetahui hubungan antara pola makan dan pantangan makan dengan kejadian KEK pada ibu hamil di Kecamatan Sedayu, Bantul, Yogyakarta.

Metode: Jenis penelitian ini adalah observasional analitik dengan rancangan cross sectional dengan pendekatan kuantitatif dan kualitatif. Sampel pada penelitian ini adalah seluruh ibu hamil yang berada di Kecamatan Sedayu Kabupaten Bantul. Metode kualitatif dengan menggunakan focus group disscussion
\end{abstract}

\footnotetext{
1 Pasca Sarjana IImu Kesehatan Masyarakat Minat Gizi dan Kesehatan Fakultas Kedokteran Universitas Gadjah Mada, JI. Farmako, Sekip UtaraYogyakarta 55281, e-mail: oktri_suprin@yahoo.co.id

2 Bagian IImu Kesehatan Anak RSUP Dr. Sardjito, Jl. Kesehatan No 1, Yogyakarta, e-mail: juffrie@indosat.net.id

${ }^{3}$ Program Studi S1 IImu Gizi, STIKES Alma Ata Yogyakarta, Jl. Ring Road Barat Daya No 1, Yogyakarta 55183,

e-mail: dewi.astiti@gmail.com
} 
(FGD) kepada kelompok ibu hamil yang KEK dan tidak KEK yang berjumlah 14 orang. Penelitian kuantitatif menggunakan metode pengambilan sampel total sampling, yang berjumlah 201 orang ibu hamil. Penelitian dilaksanakan pada bulan April hingga Juni 2014. Data dianalisis dengan menggunakan analisis univariat (deskriptif), bivariat (chi-square dan Mann Whitney) dan multivariat (regresi logistik). Data asupan energi dan protein dianalisis dengan menggunakan software Nutrisurvey.

Hasil: Hasil uji chi-square menunjukkan tidak ada hubungan antara pola makan dan pantangan makan dengan kejadian KEK pada ibu hamil ( $p>0,05)$. Sebanyak 17,91\% ibu hamil berisiko KEK, 20,99\% diantaranya mempunyai pola makan pokok (nasi) yang kurang dan 20,22\% masih mempunyai pantangan makan. Makanan yang dipantang yaitu makanan sumber protein, sumber vitamin dan mineral (buah dan sayur), dan bahan makanan sumber energi.

Kesimpulan: Pola makan dan pantangan makan pada ibu hamil tidak berhubungan dengan kejadian KEK.

KATA KUNCI: pola makan, pantangan makan, ibu hamil, KEK

\section{PENDAHULUAN}

Masa kehamilan merupakan periode yang sangat menentukan kualitas sumber daya manusia di masa depan, karena tumbuh kembang anak dipengaruhi oleh kondisinya saat masa janin dalam kandungan (1). Kekurangan energi kronik (KEK) adalah keadaan ibu menderita kekurangan makanan yang berlangsung menahun (kronis) yang mengakibatkan timbulnya gangguan kesehatan (2). KEK pada ibu hamil berdampak terhadap ibu dan bayi yang akan dilahirkan (3), seperti pertumbuhan janin yang kurang dan meningkatnya risiko kematian neonatal (4), meningkatnya risiko terjadinya stunting (5) dan berat badan lahir rendah (BBLR) (6).

KEK masih merupakan masalah kesehatan di dunia, khususnya negara berkembang. Sekitar sepertiga dari populasi di India menderita KEK (7). Prevalensi KEK pada wanita di perkotaan sebesar $56 \%$ lebih tinggi dibandingkan daerah pedesaan yaitu sebesar $36 \%$ (8). Prevalensi ibu hamil yang mengalami KEK di Indonesia tahun 2013 sebesar 23,4\% (9), sedangkan di Daerah Istimewa Yogyakarta (DIY) prevalensi ibu hamil KEK 14,8\% (10). Kabupaten Bantul merupakan salah satu kabupaten yang ada di DIY dengan prevalensi ibu hamil KEK sebesar $13,8 \%$ dan di Kecamatan Sedayu 11,4\% tahun 2011 (11).

Pola konsumsi telah diketahui sebagai salah satu faktor risiko dari masalah gizi ibu hamil (12). Pola konsumsi makan ibu hamil dipengaruhi oleh pola konsumsi keluarga dan distribusi makanan (13) yang terdiri dari jumlah, jenis, frekuensi, serta pantangan makan (14). Pantangan dalam mengonsumsi jenis makanan tertentu dapat dipengaruhi oleh faktor budaya/kepercayaan yang terdapat dalam masyarakat setempat (15). Penelitian yang dilakukan di Bogor dan Indramayu mendapatkan hasil bahwa wanita hamil dilarang memakan buah nanas dan kerak nasi (16). Dalam studi etnografi terhadap etnik Jawa yang dilakukan oleh Dinas Kesehatan Kabupaten Bantul tahun 2011 mendapati bahwa masih terdapat pantangan makan bagi ibu hamil yaitu berpantang terhadap buah dan sayur tertentu yang bisa dikatakan sebagai pengetahuan atau kearifan lokal yang ada di wilayah tersebut (11).

Pola makan yang baik perlu dibentuk sebagai upaya untuk memenuhi kebutuhan gizi, terutama ibu hamil yang membutuhkan gizi yang baik. Penelitian sebelumnya menunjukkan bahwa KEK pada ibu hamil yang ada di Bantul disebabkan beberapa hal, yaitu $28,69 \%$ disebabkan oleh pola konsumsi yang tidak baik, $17,2 \%$ memiliki frekuensi makan kurang dari 3 kali/hari dan $55,7 \%$ memiliki porsi makan selama hamil lebih sedikit atau sama dengan sebelum hamil (17). Penelitian ini bertujuan untuk mengetahui hubungan antara pola makan dan pantangan makan dengan kejadian KEK pada ibu hamil di Kecamatan Sedayu, Bantul, Yogyakarta. Kecamatan Sedayu dipilih sebagai lokasi penelitian karena merupakan daerah yang berbatasan dengan Kota Yogyakarta dan Kabupaten Sleman sehingga akses terhadap pangan terbuka luas dan arus informasi yang mudah didapatkan akan mempengaruhi status kesehatan. 


\section{BAHAN DAN METODE}

Jenis penelitian ini adalah observasional analitik dengan rancangan cross sectional dengan metode campuran, yaitu pendekatan kuantitatif dan kualitatif. Penelitian ini merupakan bagian dari penelitian yang berjudul "Status Gizi lbu Hamil dan Baduta di Kecamatan Sedayu Kabupaten Bantul D.I Yogyakarta" yang dilaksanakan oleh Alma Ata Center For Healthy Life and Food (ACHEAF) Yogyakarta. Metode campuran yang digunakan yaitu embedded konkuren, yaitu data kualitatif yang dikumpulkan untuk mendukung data kuantitatif (18). Penelitian dilakukan selama 3 bulan yakni April hingga Juni 2014. Subjek penelitian berjumlah 201 orang, yaitu seluruh ibu hamil yang berada di Kecamatan Sedayu Kabupaten Bantul yang memenuhi kriteria inklusi dan ekslusi. Kriteria inklusi yang dimaksud adalah berdomisili di wilayah Kecamatan Sedayu, setuju untuk berpartisipasi dan menandatangani formulir persetujuan dan dengan kehamilan tunggal (janin tidak kembar). Kriteria ekslusi yaitu Ibu hamil yang mengalami odema bagian atas terutama lengan tangan, tidak mempunyai tangan (cacat), dan menderita penyakit penyerta yang berat.

Variabel terikat pada penelitian ini yaitu status gizi ibu hamil KEK, variabel bebas yaitu pola makan dan pantangan makan, variabel antara yaitu tingkat kecukupan energi, tingkat kecukupan protein, dan penyakit infeksi serta variabel luar yaitu ketersediaan pangan, tingkat pengetahuan, tingkat pendapatan keluarga, dan umur kehamilan. Instrumen yang digunakan pada penelitian ini yaitu pita lingkar lengan atas (LILA), buku ibu hamil atau kartu menuju sehat (KMS), semi-quantitative food frequency questionnaire (SQ-FFQ), food model, panduan pertanyaan focus group discussion (FGD).

Data diambil dengan melakukan wawancara langsung kepada 201 responden mengenai variabel penelitian dan FGD kepada ibu hamil yang KEK dan tidak KEK berjumlah 14 orang untuk menggali informasi mengenai adanya kebiasaan memantang makanan tertentu selama hamil dan jenisnya dengan menggunakan panduan pertanyaan FGD. Daftar ibu hamil diperoleh dari Puskesmas Sedayu I dan Sedayu II serta dari kader posyandu di masingmasing posyandu.
Data dianalisis menggunakan analisis univariat (deskriptif), bivariat (chi-square), dan multivariat (regresi logistik). Data asupan energi dan protein dianalisis dengan menggunakan software Nutrisurvey. Penelitian ini telah mendapatkan persetujuan dari Komisi Etik Penelitian Kedokteran dan Kesehatan Fakultas Kedokteran Universitas Gadjah Mada nomor Ref: KE/FK/382/EC tahun 2014.

\section{HASIL}

\section{Karakteristik subjek penelitian}

Analisis univariat digunakan dalam penelitian ini untuk mendeskripsikan distribusi frekuensi dan distribusi karakteristik responden. Karakteristik variabel yang dianalisis univariat meliputi variabel terikat yaitu risiko KEK pada ibu hamil, variabel bebas yaitu pola makan dan pantangan makan, variabel antara yaitu tingkat asupan energi, tingkat asupan protein, penyakit infeksi dan variabel luar yaitu ketersediaan pangan, tingkat pengetahuan, tingkat pendapatan keluarga, dan umur kehamilan dapat dilihat pada Tabel 1 .

Berdasarkan Tabel 1 tersebut dapat dilihat bahwa sebanyak $17,91 \%$ ibu hamil mengalami KEK. Ibu hamil yang mempunyai pola makan yang baik sejumlah $59,70 \%$ dan tidak terdapat pantangan makan sejumlah $55,72 \%$. Sebagian besar ibu hamil mempunyai tingkat asupan energi yang cukup $(70,65 \%)$, tingkat asupan protein yang rendah $(58,71 \%)$, tidak mempunyai penyakit infeksi $(71,14 \%)$, dan berada dalam kondisi terjamin ketersediaan pangannya (83,58\%). Tingkat pengetahuan ibu hamil sebagian besar berada pada kategori kurang $(73,63 \%)$, pendapatan keluarga yang rendah $(56,22 \%)$, dan berada pada umur kehamilan trimester $3(69,65 \%)$.

Gambar 1 merupakan gambaran distribusi pola makan subjek pada penelitian ini terkait frekuensi makan dan jumlah makanan pokok per harinya. Sebagian besar subjek memiliki pola makan yang baik yaitu dengan frekuensi $\geq 2$ kali per hari dan jumlah berat makanan pokok yang dikonsumsi $\geq$ nilai median (400 g). Frekuensi makan pokok subjek dalam sehari bervariasi dari 1 sampai 6 kali sehari, sedangkan jumlah berat makanan pokok yang dikonsumsi subjek dalam sehari yang paling rendah adalah 50 gram dan tertinggi adalah 1.000 gram. 
Tabel 1. Distribusi karakteristik responden

\begin{tabular}{|c|c|c|}
\hline Variabel & $\mathbf{n}$ & $\%$ \\
\hline \multicolumn{3}{|l|}{ Status gizi } \\
\hline KEK $($ LILA $<23,5 \mathrm{~cm})$ & 36 & 17,91 \\
\hline Tidak KEK (LILA $\geq 23,5 \mathrm{~cm}$ ) & 165 & 82,09 \\
\hline \multicolumn{3}{|l|}{ Pola makan } \\
\hline $\begin{array}{l}\text { Tidak baik (<2 kali \& jumlah } \\
\text { kurang) }\end{array}$ & 3 & 1,5 \\
\hline $\begin{array}{l}\text { Kurang baik ( } \geq 2 \text { kali } \& \text { jumlah } \\
\quad \text { kurang atau }<2 \text { kali \& cukup) }\end{array}$ & 78 & 38,80 \\
\hline Baik ( $\geq 2$ kali \& cukup) & 120 & 59,70 \\
\hline \multicolumn{3}{|l|}{ Pantangan makan } \\
\hline Ada & 89 & 44,28 \\
\hline Tidak ada & 112 & 55,72 \\
\hline \multicolumn{3}{|l|}{ Tingkat asupan energi (kkal) } \\
\hline Rendah $(<70 \%$ AKG) & 59 & 29,35 \\
\hline Cukup ( $\geq 70 \%$ AKG) & 142 & 70,65 \\
\hline \multicolumn{3}{|l|}{ Tingkat asupan protein $(\mathrm{g})$} \\
\hline Rendah (<90\% AKG) & 118 & 58,71 \\
\hline Cukup ( $\geq 90 \%$ AKG) & 83 & 41,29 \\
\hline \multicolumn{3}{|l|}{ Penyakit infeksi } \\
\hline Ada & 58 & 28,86 \\
\hline Tidak ada & 143 & 71,14 \\
\hline \multicolumn{3}{|l|}{ Ketersediaan pangan } \\
\hline Rawan kelaparan tingkat berat & 6 & 2,99 \\
\hline Rawan kelaparan tingkat sedang & 7 & 3,48 \\
\hline Rawan tanpa kelaparan & 20 & 9,95 \\
\hline Terjamin & 168 & 83,58 \\
\hline \multicolumn{3}{|l|}{ Tingkat pengetahuan } \\
\hline Kurang & 148 & 73,63 \\
\hline Cukup & 53 & 26,37 \\
\hline \multicolumn{3}{|l|}{ Tingkat pendapatan keluarga } \\
\hline Rendah ( $\leq$ median, $\operatorname{Rp} 2.000 .000)$ & 113 & 56,22 \\
\hline Tinggi (>median, Rp 2.000.000) & 88 & 43,78 \\
\hline \multicolumn{3}{|l|}{ Umur kehamilan } \\
\hline Trimester 1 & 4 & 2,00 \\
\hline Trimester 2 & 57 & 28,35 \\
\hline Trimester 3 & 140 & 69,65 \\
\hline
\end{tabular}

Hasil analisis bivariat untuk membuktikan hubungan antara pola makan dan status gizi ibu hamil dapat dilihat pada Tabel 2. Berdasarkan Tabel 2 didapatkan bahwa pada kelompok ibu hamil yang KEK, persentasi pola makan yang kurang lebih tinggi dari pola makan yang baik masing-masing sebesar $20,99 \%$ dan $15,83 \%$. Dari uji statistik didapatkan nilai $p>0,05$ yang menunjukkan tidak terdapat hubungan yang signifikan antara pola makan dengan status gizi ibu hamil.

Hubungan antara pantangan dan status gizi ibu hamil dapat dilihat pada Tabel 3. Berdasarkan Tabel 3 didapatkan bahwa pada kelompok ibu hamil yang KEK, persentase ibu yang mempunyai pantangan makan lebih tinggi dibandingkan dengan tidak ada pantangan masing-masing sebesar $20,22 \%$ dan $16,07 \%$. Dari uji statistik didapatkan nilai $p>0,05$ yang menunjukkan tidak terdapat

Tabel 2. Analisis bivariat pola makan dengan status gizi ibu hamil

\begin{tabular}{|c|c|c|c|c|c|c|}
\hline \multirow{3}{*}{$\begin{array}{l}\text { Karak- } \\
\text { teristik }\end{array}$} & \multicolumn{4}{|c|}{ Status gizi ibu hamil } & & \multirow{3}{*}{$\begin{array}{c}\text { RP } \\
(95 \% \mathrm{Cl})\end{array}$} \\
\hline & \multicolumn{2}{|c|}{ KEK } & \multicolumn{2}{|c|}{ Tidak KEK } & & \\
\hline & $\mathbf{n}$ & $\%$ & $n$ & $\%$ & & \\
\hline \multicolumn{7}{|l|}{ Dola Makan } \\
\hline & 17 & & 64 & 79,61 & 0 & \\
\hline & & & 101 & 84 & & \\
\hline \multicolumn{7}{|c|}{$\begin{array}{l}\text { frekuensi makan }<2 \text { x perhari dan konsumsi makanan } \\
\text { pokok }<400 \mathrm{~g} / \text { hari }\end{array}$} \\
\hline \multicolumn{7}{|c|}{$\begin{array}{l}\text { ** frekuensi makan } \geq 2 \times \text { per hari dan konsumsi makanan } \\
\quad \text { pokok } \geq 400 \mathrm{~g} / \mathrm{hari}\end{array}$} \\
\hline
\end{tabular}

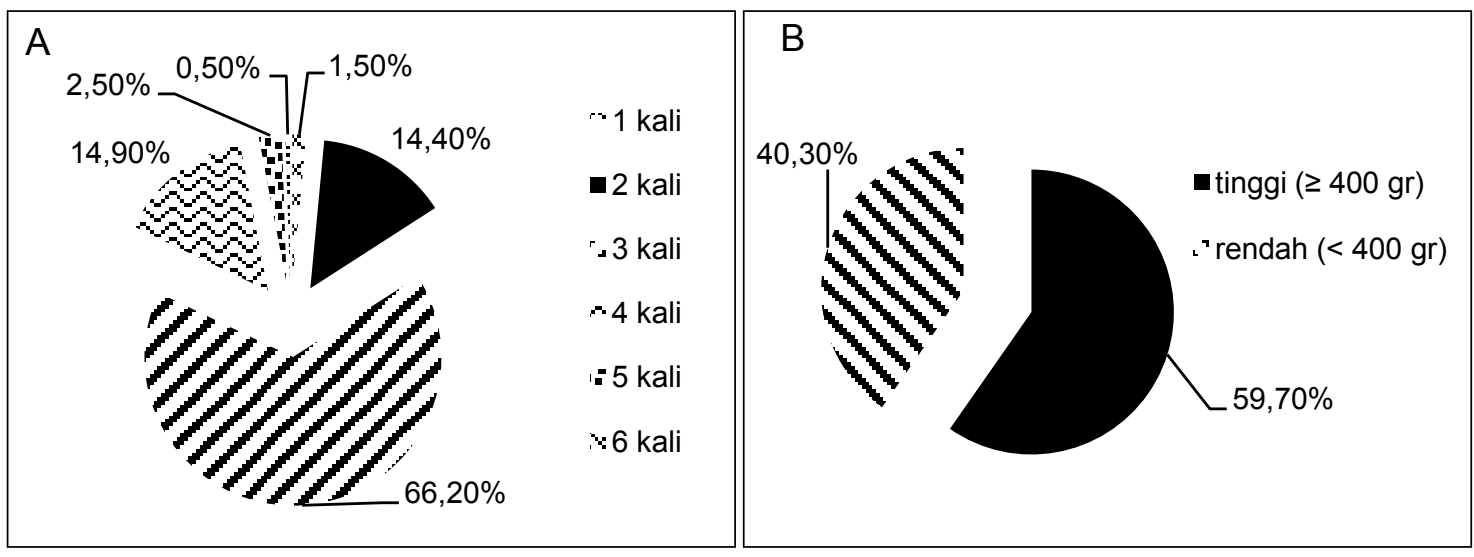

Gambar 1. Distribusi frekuensi (A) dan jumlah makan pokok ibu hamil (B) 
Tabel 3. Analisis bivariat pantangan makan dengan status gizi ibu hamil

\begin{tabular}{|c|c|c|c|c|c|c|}
\hline \multirow{3}{*}{$\begin{array}{l}\text { Karak- } \\
\text { teristik }\end{array}$} & \multicolumn{4}{|c|}{ Status gizi ibu hamil } & \multirow{3}{*}{ p } & \multirow{3}{*}{$\begin{array}{c}\text { RP } \\
(95 \% \mathrm{Cl})\end{array}$} \\
\hline & \multicolumn{2}{|c|}{ KEK } & \multicolumn{2}{|c|}{$\begin{array}{c}\text { Tidak } \\
\text { KEK }\end{array}$} & & \\
\hline & $\mathbf{n}$ & $\%$ & $\mathbf{n}$ & $\%$ & & \\
\hline \multicolumn{7}{|l|}{ Pantangan } \\
\hline Ada & 18 & 20,22 & 71 & 79,78 & 0,44 & 1,32 \\
\hline Tidak ada & 18 & 16,07 & 94 & 83,93 & & $(0,96-2,27)$ \\
\hline
\end{tabular}

hubungan yang signifikan antara pantangan makan dengan status gizi ibu hamil.

Gambar 2 memperlihatkan jenis makanan yang dipantang ibu hamil yang KEK. Satu orang ibu hamil bisa memantang lebih dari satu jenis makanan, sedangkan hampir sebagian besar memantang makan sayuran jenis tertentu. Hasil kuantitatif ini didukung dengan hasil kualitatif yang didapatkan yaitu masih terdapat pantangan makan pada ibu hamil. Berikut pernyataan beberapa ibu dalam kegiatan FGD kelompok ibu hamil yang KEK:

"Makanan pare, daun pepaya, makanan yang pahit. Ibu bidan yang menganjurkan tidak boleh makan karena bisa menghambat jalan

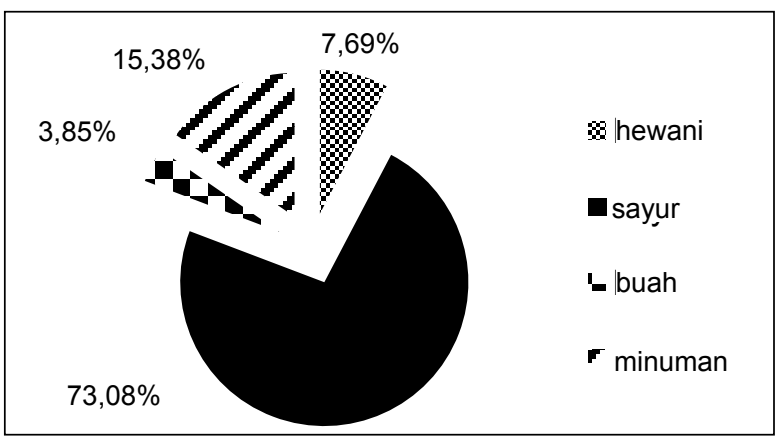

Gambar 2. Jenis makanan/minuman ibu hamil yang KEK lahir bayi. Minum es batu juga tidak boleh, nanti bayinya besar. Buah duren, tape, nangka yang panas-panas" (ST)

"Pare dan pepaya kata bu bidan, tapi aku juga kalau pengen banget makan dikit. Kata si mbah kalau makan lele nanti anaknya nakal, tetapi masih dimakan. Buah nanas gak boleh" (RH)

Gambar 3 memperlihatkan jenis makanan yang dipantang ibu hamil yang tidak KEK. Sebagian besar memantang minuman tertentu. Hasil kuantitatif ini didukung dengan hasil kualitatif yang didapatkan yaitu masih terdapat pantangan makan pada ibu hamil. Berikut pernyataan beberapa ibu dalam kegiatan FGD kelompok ibu hamil yang tidak KEK:

“....Jamu, katanya gak baik, bisa keruh air ketuban. Kata ibu mertua. Berbahaya buat bayi" (FJ)

Pada penelitian ini, jenis makanan pantangan ibu hamil dikelompokan menjadi 4 dan 1 kategori minuman (Tabel 4). Banyak alasan ibu hamil dalam menghindari keempat makanan tersebut dan sumber informasi (Tabel 5).

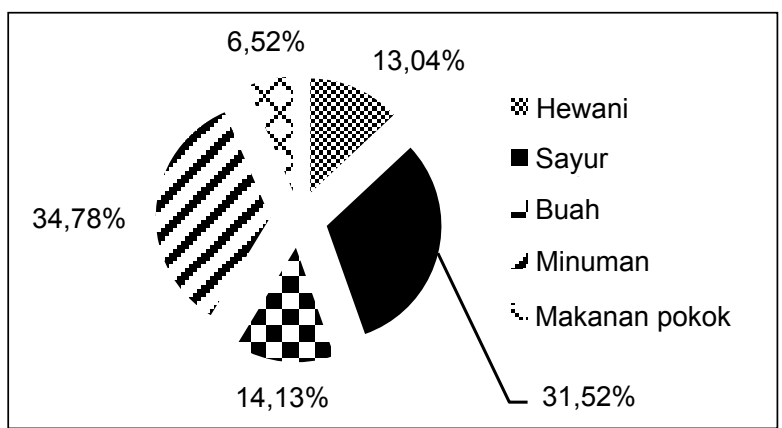

Gambar 3. Jenis makanan/minuman ibu hamil yang tidak KEK

Tabel 4. Jenis makanan pantangan responden

\begin{tabular}{ccccc}
\hline Makanan hewani & Sayuran & Buahan & Minuman & Makanan pokok \\
\hline Makanan laut & Pare & Rasa asam & Beralkohol & Tape \\
Udang & Daun pepaya & Buah nangka & Bersoda & Roti \\
Lele & Daun singkong & Nanas & Teh & Mie instan \\
Belut & Sayur mentah (lalapan) & Durian & Kopi & \\
Telur boiler & Buah pepaya muda & & Jamu & \\
Susu & Jamur & & Minuman dingin & \\
Ikan asin & Petai & & & \\
Jeroan & Cabai & & \\
Sarden kaleng & & & \\
\hline
\end{tabular}


Tabel 5. Alasan dan sumber informasi yang mempengaruhi ibu hamil dalam menghindari makanan tertentu

\begin{tabular}{ll}
\hline \multicolumn{1}{c}{ Alasan } & \multicolumn{1}{c}{ Sumber informasi } \\
\hline Berbahaya untuk janin & Kader posyandu \\
Berbahaya untuk ibu hamil & Kemauan sendiri \\
Bertentangan dengan ajaran leluhur dan orang tua & Tetangga \\
Membuat air ketuban menjadi keruh & Ibu atau nenek \\
Membuat zat gizi bisa tidak masuk ke janin & Ibu bidan \\
Bisa membuat gatal atau alergi & \\
Bisa menurunkan $\mathrm{Hb}$ & \\
Bisa membuat panas & \\
Bisa membuat sulit melahirkan & \\
\hline
\end{tabular}

Tabel 6. Hubungan variabel antara dan luar dengan dengan kejadian KEK pada ibu hamil

\begin{tabular}{|c|c|c|c|c|c|c|}
\hline \multirow{3}{*}{ Karakteristik } & \multicolumn{4}{|c|}{ Status gizi ibu hamil } & \multirow{3}{*}{ p } & \multirow{3}{*}{$\begin{array}{c}\text { RP } \\
(95 \% \mathrm{Cl})\end{array}$} \\
\hline & \multicolumn{2}{|c|}{ KEK } & \multicolumn{2}{|c|}{ Tidak KEK } & & \\
\hline & $\mathbf{n}$ & $\%$ & $\mathbf{n}$ & $\%$ & & \\
\hline \multicolumn{7}{|l|}{ Tingkat asupan energi } \\
\hline Rendah & 18 & 30,51 & 41 & 69,49 & $0,03^{*}$ & 3,02 \\
\hline Cukup & 18 & 12,68 & 124 & 87,32 & & \\
\hline \multicolumn{7}{|l|}{ Tingkat asupan protein } \\
\hline Rendah & 26 & 22,03 & 92 & 77,97 & 0,06 & 2,06 \\
\hline Cukup & 10 & 12,05 & 73 & 87,95 & & \\
\hline \multicolumn{7}{|l|}{ Penyakit infeksi } \\
\hline Ada & 11 & 18,97 & 47 & 81,03 & 0,80 & 1,10 \\
\hline Tidak Ada & 25 & 17,48 & 118 & 82,52 & & \\
\hline \multicolumn{7}{|l|}{ Ketersediaan pangan } \\
\hline Tidak terjamin & 11 & 33,33 & 22 & 66,67 & $0,01^{*}$ & 2,81 \\
\hline Terjamin & 25 & 14,88 & 143 & 85,12 & & \\
\hline \multicolumn{7}{|l|}{ Tingkat pengetahuan } \\
\hline Kurang & 26 & 17,57 & 122 & 82,43 & 0,83 & 0,91 \\
\hline Cukup & 10 & 17,91 & 43 & 81,13 & & \\
\hline \multicolumn{7}{|c|}{ Tingkat pendapatan keluarga } \\
\hline Rendah & 28 & 24,78 & 85 & 75,22 & $0,00^{*}$ & 3,29 \\
\hline Tinggi & 8 & 9,09 & 80 & 90,91 & & \\
\hline \multicolumn{7}{|l|}{ Umur kehamilan } \\
\hline Trimester 1 dan 2 & 15 & 24,59 & 46 & 75,41 & 0,10 & 1,84 \\
\hline Trimester 3 & 21 & 15,00 & 119 & 85,00 & & \\
\hline
\end{tabular}

* Signifikan $(p<0,05)$

Berdasarkan Tabel 6 tersebut dapat dilihat bahwa ada tiga variabel yang mempunyai hubungan yang signifikan secara statistik terhadap variabel terikat yaitu variabel tingkat asupan energi, ketersediaan pangan, dan tingkat pendapatan. Variabel luar yang lain yaitu tingkat asupan protein, penyakit infeksi, tingkat pengetahuan, dan umur kehamilan tidak berpengaruh secara signifikan terhadap variabel terikat.

Pada Tabel 7 menunjukkan hubungan antara pola makan dan pantangan makan terhadap kejadian
KEK pada ibu hamil setelah dikontrol oleh variabel tingkat asupan energi, tingkat asupan protein, ketersediaan pangan, tingkat pendapatan dan umur kehamilan. Model terbaik yang dipilih yaitu model 7 . Model ini dipilih karena mempunyai nilai $\mathrm{R}^{2}$ yang paling besar, mempunyai nilai deviance yang paling kecil dan sudah mempertimbangkan variabel yang lain di dalam analisis. Dengan demikian, dapat disimpulkan bahwa variabel yang bisa mempengaruhi terjadinya KEK pada ibu hamil yaitu tingkat asupan energi dan tingkat pendapatan keluarga. 
Tabel 7. Analisis multivariat

\begin{tabular}{|c|c|c|c|c|c|c|c|}
\hline \multirow{3}{*}{ Variabel } & \multirow[b]{2}{*}{$\begin{array}{c}\text { Model } 1 \\
\text { OR } \\
(95 \% \mathrm{Cl}) \\
\end{array}$} & \multicolumn{6}{|c|}{ Status KEK } \\
\hline & & $\begin{array}{c}\text { Model } 2 \\
\text { OR } \\
(95 \% \mathrm{CI})\end{array}$ & $\begin{array}{c}\text { Model } 3 \\
\text { OR } \\
(95 \% \mathrm{Cl})\end{array}$ & $\begin{array}{c}\text { Model } 4 \\
\text { OR } \\
(95 \% \mathrm{Cl})\end{array}$ & $\begin{array}{c}\text { Model } 5 \\
\text { OR } \\
(95 \% \mathrm{Cl})\end{array}$ & $\begin{array}{c}\text { Model } 6 \\
\text { OR } \\
(95 \% \mathrm{Cl})\end{array}$ & $\begin{array}{c}\text { Model } 7 \\
\text { OR } \\
(95 \% \mathrm{Cl})\end{array}$ \\
\hline & $\mathbf{P}$ & $\mathbf{p}$ & $\mathbf{p}$ & $\mathbf{p}$ & $\mathbf{p}$ & $\mathbf{p}$ & $\mathbf{p}$ \\
\hline Pola makan & 1,18 & 0,77 & 1,00 & 1,11 & 1,29 & 1,24 & 0,94 \\
\hline Kurang & $0,55-2,54$ & $0,33-1,80$ & $0,45-2,20$ & $0,51-2,43$ & $0,59-2,82$ & $0,57-2,68$ & $0,39-2,25$ \\
\hline Baik & 0,66 & 0,56 & 0,99 & 0,78 & 0,52 & 0,58 & 0,89 \\
\hline Pantangan makan & 1,31 & 1,44 & 1,46 & 1,31 & 1,22 & 1,22 & 1,27 \\
\hline Ada & $0,64-2,70$ & $0,68-3,03$ & $0,69-3,05$ & $0,62-2,74$ & $0,58-2,57$ & $0,58-2,54$ & $0,58-2,79$ \\
\hline Tidak ada & 0,46 & 0,33 & 0,31 & 0,47 & 0,59 & 0,59 & 0,55 \\
\hline Tingkat asupan energi & & 3,37 & & & & & 3,05 \\
\hline Rendah & & $1,50-7,57$ & & & & & $1,18-7,92$ \\
\hline Cukup & & $0,00^{*}$ & & & & & $0,02^{*}$ \\
\hline Tingkat asupan protein & & & 2,17 & & & & 1,04 \\
\hline Rendah & & & $0,95-4,92$ & & & & $0,39-2,80$ \\
\hline Cukup & & & 0,06 & & & & 0,93 \\
\hline Ketersediaan pangan & & & & 2,83 & & & 2,00 \\
\hline Tidak terjamin & & & & $1,22-6,58$ & & & $0,79-5,05$ \\
\hline Terjamin & & & & $0,01^{*}$ & & & 0,14 \\
\hline Tingkat pendapatan & & & & & 3,31 & & 2,94 \\
\hline Rendah & & & & & $1,42-7,74$ & & $1,19-7,25$ \\
\hline Tinggi & & & & & $0,00^{*}$ & & $0,01^{*}$ \\
\hline Umur kehamilan & & & & & & 1,82 & 1,97 \\
\hline Berisiko & & & & & & $0,85-3,88$ & $0,88-4,42$ \\
\hline Tidak berisiko & & & & & & 0,12 & 0,09 \\
\hline $\mathrm{R}^{2}$ & 0,004 & 0,050 & 0,023 & 0,033 & 0,050 & 0,016 & 0,120 \\
\hline Log likelihood & $-94,0909$ & $-89,6831$ & $-92,250$ & $-91,353$ & $-89,688$ & $-92,895$ & $-83,138$ \\
\hline $\mathrm{N}$ & 201 & 201 & 201 & 201 & 201 & 201 & 201 \\
\hline
\end{tabular}

\section{BAHASAN}

\section{Pola makan dengan kejadian KEK}

Pola makan merupakan gambaran mengenai jumlah atau porsi makan, jenis makan, dan frekuensi makan seseorang (19). Tidak adanya hubungan antara pola makan dengan kejadian KEK dapat disebabkan KEK tidak hanya dipengaruhi oleh pola makan saja melainkan banyak faktor lain. Hasil penelitian didapatkan bahwa variabel lain yang mempengaruhi terjadinya KEK pada ibu hamil yaitu tingkat asupan energi, tingkat ketersediaan pangan, dan tingkat pendapatan keluarga. Hasil analisis multivariat didapatkan bahwa variabel yang mempengaruhi terjadinya KEK pada ibu hamil yaitu tingkat asupan energi dan tingkat pendapatan. Hal ini sesuai teori yang menyatakan bahwa status gizi seseorang secara langsung dipengaruhi oleh asupan energi (13).
Faktor lain yang mempengaruhi tidak adanya hubungan antara pola makan dan kejadian KEK yaitu dalam analisis tidak mempertimbangkan golongan makanan lain yang memberikan kontribusi terhadap jumlah Kalori, sedangkan dalam perhitungan asupan energi seseorang memasukan semua jenis makanan yang lain yang masing-masing berkontribusi terhadap jumlah kalori $(19,20)$. Frekuensi makan juga berkaitan dengan pemenuhan kebutuhan zat gizi yang dibutuhkan oleh tubuh. Pada ibu hamil, pola makan yang dianjurkan bagi ibu hamil yaitu porsi makan yang kecil tapi sering minimal lima kali sehari $(3,21,22,23)$. Jumlah atau porsi makan yang dikonsumsi seseorang mempengaruhi zat gizi yang masuk ke dalam tubuh. Hasil penelitian menunjukkan bahwa sebagian besar ibu hamil mengonsumsi makanan pokok $\geq 400$ gram yaitu sebesar $59,70 \%$. Konsumsi makanan pokok per 
hari yang dianjurkan sebesar 300 sampai 500 gram (20).

\section{Pantangan makan dengan kejadian KEK}

Makanan yang dikonsumsi manusia digunakan untuk mempertahankan kelangsungan hidupnya, tetapi ada yang beranggapan bahwa satu atau beberapa makanan dianggap berbahaya bagi yang memakannya. Pantangan makan merupakan perilaku seseorang untuk tidak mengonsumsi makanan tertentu (14). Penelitian lain mendapatkan bahwa ada hubungan yang signifikan antara budaya pantang makan dengan kejadian KEK (24). Berdasarkan hasil penelitian ini didapatkan bahwa pantangan makan tidak mempunyai hubungan yang signifikan terhadap kejadian KEK dengan $p>0,05(p=0,44)$.

Hasil penelitian ini sejalan dengan penelitian yang menyatakan bahwa tidak terdapat hubungan yang signifikan antara pantangan makan dengan kejadian KEK pada ibu hamil di Kabupaten Banjarnegara (25). Penelitian lain mengenai pola konsumsi makan ibu hamil di Jawa Tengah mendapatkan bahwa pantangan makan berpengaruh terhadap konsumsi bahan makanan sumber protein, tetapi tidak berpengaruh secara signifikan terhadap zat gizi energi (26).

Tidak terdapatnya hubungan yang signifikan antara pantangan makan dengan KEK pada ibu hamil disebabkan jenis makanan yang dipantang oleh ibu hamil merupakan makanan yang mempunyai kontribusi energi yang kecil dan tidak mempunyai zat gizi yang tinggi yang dapat mempengaruhi status gizi pada ibu hamil. Makanan pokok yang dipantang ibu hamil yaitu roti, tape, dan mie instan. Makanan sumber protein yang dipantang yaitu ikan lele, jeroan, daging, ikan, udang. Makanan sumber vitamin dan mineral yaitu sayuran (daun pepaya dan pare) merupakan makanan yang banyak dipantang oleh ibu hamil baik yang KEK maupun yang tidak KEK. Hal lain yang menyebabkan perbedaan hasil penelitian ini dengan penelitian lain yaitu pantangan makan yang berbeda.

Jika dilihat dari jenis pantangan makan yang terdapat pada ibu hamil di daerah Sedayu, Bantul mempunyai korelasi jauh dengan KEK. Akan tetapi, hal ini bisa dimungkinkan karena tidak ada makanan yang lain yang tersedia di dalam rumah tangga. Hal ini menunjukkan terdapat hubungan yang erat kaitannya dengan tingkat kesejahteraan. Daftar jenis makanan dan minuman yang dipantang ibu hamil dapat dilihat pada Tabel 4. Berdasarkan data tersebut terlihat bahwa ada pantangan yang baik dan ada pantangan yang tidak baik. Sebagian besar makanan yang tidak baik dipantang karena merupakan makanan yang bergizi tinggi dan baik untuk dikonsumsi ibu hamil. Adapun makanan dan minuman yang memang sebaiknya dipantang oleh ibu hamil yaitu makanan yang mengandung gas (durian, tape), makanan yang mengandung pengawet (mie instan, sarden kaleng), dan minuman yang memberikan efek negatif (minuman beralkohol, bersoda, teh, kopi, jamu). Baik kopi dan teh mengandung kafein yang bisa memberikan dampak negatif jika dikonsumsi berlebihan. Konsumsi teh, kopi, alkohol, bersoda, dan jamu memberikan dampak negatif bagi kesehatan (27-30).

Pantangan makan masih banyak terdapat di berbagai belahan dunia, baik di luar negeri maupun dalam negeri. Hal ini terjadi karena banyak kepercayaan, kebiasaan, dan adat istiadat yang berhubungan dengan soal makan dan makanan. Setiap suku bangsa mempunyai cara-cara sendiri dalam hal makanan yang dipilihnya dan memberikan konsekuensi terhadap status gizi (31-33). Masalah gizi juga dipengaruhi oleh kepercayaan-kepercayaan yang keliru mengenai hubungan antara makanan dengan kesehatan, pantangan yang mencegah seseorang memanfaatkan sebaik-baiknya makanan yang tersedia baginya (34-36). Berpantang terhadap makanan tertentu tidak menjadi masalah jika sesuai dengan kondisi kesehatan ibu hamil dan anjuran dokter. Berbeda jika makanan yang dipantang tidak berhubungan dengan kondisi ibu, dan makanan yang dipantang mempunyai zat gizi yang tinggi. $\mathrm{Hal}$ ini bisa berakibat kepada pembatasan jenis makanan yang akan dimakan ibu hamil dan pada akhirnya akan mempengaruhi asupan gizi jika terjadi pengurangan konsumsi makan dan tidak punya makanan pengganti (34).

\section{Variabel luar dengan kejadian KEK}

Hasil analisis bivariat variabel luar pada Tabel 3 menunjukkan bahwa variabel luar yang mempunyai 
hubungan yang signifikan terhadap kejadian KEK yaitu tingkat asupan energi, ketersediaan pangan, dan tingkat pendapatan. Adapun variabel yang tidak mempunyai hubungan yang signifikan terhadap kejadian KEK, yaitu tingkat asupan protein, penyakit infeksi, tingkat pengetahuan, dan umur kehamilan.

Asupan energi merupakan zat gizi yang penting dalam terjadinya KEK. Sesuai dengan definisi KEK itu sendiri yaitu suatu kondisi terjadi kekurangan asupan energi dibanding kebutuhan. Hal ini sejalan dengan penelitian yang menyatakan bahwa terdapat hubungan yang signifikan antara pola makan dari asupan energi dan ketersediaan pangan dengan kejadian KEK pada ibu hamil di daerah Sumatera Utara (37). Penyakit infeksi berpengaruh terhadap status gizi seseorang dan juga sebaliknya. Pada penelitian ini penyakit infeksi yang dimaksud adalah diare, demam, dan batuk. Hasil analisis didapatkan bahwa tidak terdapat hubungan yang signifikan antara penyakit infeksi dengan kejadian KEK pada ibu hamil. Hal ini mungkin disebabkan penyakit infeksi yang masuk pada penelitian ini pada umumnya tidak membutuhkan waktu pemulihan yang lama sehingga tidak begitu berpengaruh terhadap status gizi ibu hamil. Pengetahuan merupakan hasil seseorang melakukan pengindraan terhadap suatu objek tertentu yang diorganisir dengan pengalaman. Pengetahuan tentang gizi akan membantu seseorang dalam memilih bahan makanan yang akan dikonsumsinya. Pada penelitian didapatkan tidak terdapat hubungan yang signifikan antara pengetahuan dengan kejadian KEK pada ibu hamil. Hal ini dikarenakan pengetahuan dipengaruhi oleh berbagai hal dalam proses pembentukannya, seperti persepsi, pengalaman, nilai sosial budaya, dan masyarakat (38).

Tingkat pendapatan mempengaruhi konsumsi makanan pada keluarga. Keluarga yang mempunyai pendapatan tinggi lebih mampu menyediakan pilihan makanan yang bergizi untuk keluarganya dibanding keluarga yang berpenghasilan rendah. Penelitian ini mendapatkan bahwa terdapat hubungan yang signifikan antara tingkat pendapatan dengan kejadian KEK. Hasil ini sejalan dengan penelitian di Bangladesh yang menunjukkan bahwa wanita usia subur yang tinggal di daerah pedalaman yang mempunyai pendapatan keluarga yang rendah mempunyai status gizi yang lebih rendah dibanding dengan wanita yang mempunyai pendapatan keluarga yang lebih tinggi (36).

Pola makan ibu hamil juga dipengaruhi oleh umur kehamilan. Ibu hamil muda trimester 1 yang nafsu makannya menurun cenderung untuk makan lebih sedikit. Akibatnya, zat gizi yang masuk di dalam tubuh akan sedikit. Memasuki trimester 2, kondisi ibu hamil sudah mulai stabil sehingga asupan makan lebih banyak untuk mengejar berat badan yang turun pada trimester 1 . Oleh karena itu, risiko terjadinya KEK pada ibu hamil lebih tinggi pada trimester 1 dan 2, dan jarang pada trimester 3 . Hal ini sejalan dengan hasil penelitian yang didapatkan bahwa persentase kelompok ibu hamil yang KEK berada pada trimester 1 dan 2 lebih tinggi dibanding ibu yang berada pada trimester 3 masing-masing sebesar $24,59 \%$ dan $15 \%$.

\section{KESIMPULAN DAN SARAN}

Pada penelitian ini didapatkan bahwa tidak terdapat hubungan yang signifikan antara pola makan dan pantangan makan dengan kejadian KEK pada ibu hamil. KEK pada ibu hamil secara bersama-sama dipengaruhi oleh tingkat asupan energi dan tingkat pendapatan keluarga. Pada analisis kualitatif didapatkan bahwa masih terdapat pantangan makan pada ibu hamil yaitu perilaku negatif yang menghindari konsumsi jenis makanan tertentu karena pengaruh budaya yang ada di masyarakat setempat. Makanan yang dipantang yaitu makanan sumber protein, sumber vitamin, mineral (buah dan sayur), dan bahan makanan sumber energi yang berasal dari makanan pokok yaitu roti dan mie instan.

Hasil penelitian ini merekomendasikan kepada Dinas Kesehatan Kabupaten Bantul untuk melakukan pendidikan gizi untuk meningkatkan pengetahuan gizi kepada ibu hamil dan kader yaitu tentang pola makan yang baik dan menu seimbang yang dibutuhkan ibu hamil dan mengubah persepsi yang salah mengenai pantangan makan saat hamil, menjalin komunikasi yang intensif kepada para 
tokoh masyarakat, dan sosialisasi kepada remaja agar mempersiapkan diri pada masa prenatal dan postnatal sehingga dapat mendeteksi dini risiko kejadian KEK.

\section{RUJUKAN}

1. Atmarita, Tatang. Analisis situasi gizi dan kesehatan masyarakat. Jakarta: Direktorat Gizi Masyarakat, Departemen Kesehatan; 2004.

2. Departemen Kesehatan RI. Program gizi makro. Jakarta: Direktorat Gizi Masyarakat Depkes; 2002.

3. Arisman M. Gizi dalam daur kehidupan. Jakarta: Penerbit Buku Kedokteran EGC; 2009.

4. Black R, Victora C, Walker S, Bhutta Z, Christian $\mathrm{P}$, de Onis $\mathrm{M}$, et al. Maternal and child undernutrition and overweight in lowincome and middle-income countries. Lancet. 2013;382(9890):427-51.

5. Shrimpton R, Kachondham Y. Analysing the causes of child stunting in DPRK. Pyongyang: DPRK; 2003.

6. Lewit E, Kerrebrock N. Population-based growth stunting. Summer fall. 1997;7(2):149-56.

7. Venkaiah K, Brahmam, Vijayaraghavan. Application of factor analysis to identify dietary patterns and use of factor scores to study their relationship with nutritional status of adult rural populations. J Heath Popul Nutr. 2011;29(4):327-38.

8. Rao K, Balakhrisna M, Arlappa N, Laxmaiah A, Brahmam G. Diet and nutritional status of woman in India. J Hum Ecol. 2010;3:165-70.

9. Kemenkes RI. Laporan hasil riset kesehatan dasar 2013. Jakarta: Badan Litbangkes RI; 2013.

10. Dinas Kesehatan Provinsi DIY. Profil kesehatan Provinsi DI Yogyakarta 2011. Yogyakarta: Dinas Kesehatan Yogyakarta; 2011.

11. Dinas Kesehatan Kabupaten Bantul. Profil gizi Kabupaten Bantul 2012. Bantul: Dinas Kesehatan Kabupaten Bantul; 2012.

12. Fatimah, Hadju V, Bahar B, Abdullah Z. Pola konsumsi dan kadar hemoglobin pada ibu hamil di Kabupaten Maros, Sulawesi Selatan. Makara Kesehat. 2011;15(1):31-6.
13. Soekirman. Ilmu gizi dan aplikasinya. Jakarta: Departemen Pendidikan Nasional; 2000.

14. Suhardjo. Sosio budaya gizi. Bogor: Institut Pertanian Bogor; 1989.

15. Sulistyoningsih $\mathrm{H}$. Gizi untuk kesehatan ibu dan anak. Yogyakarta: Graha IImu; 2011.

16. Khomsan et al. Studi tentang pengetahuan gizi ibu dan kebiasaan makan pada rumah tangga di daerah dataran tinggi dan pantai. JGIZIPANGAN. 2006;1(1):23-8.

17. Susilo J. Hubungan antara intake zat besi, kalsium, tanin, fitat, dan oksalat dengan kadar $\mathrm{Hb}$ ibu hamil di Kabupaten Bantul, Yogyakarta. Universitas Gadjah Mada; 2000.

18. Cresswell. Research design pendekatan kualitatif, kuantitatif, dan mixed edisi ketiga. Yogyakarta: Pustaka Pelajar; 2010.

19. Sediaoetama. IImu gizi untuk mahasiswa dan profesi jilid II. Jakarta: Dian Rakyat; 2004.

20. Almatsier S. Prinsip dasar ilmu gizi. Jakarta: Gramedia Pustaka Utama; 2009.

21. Khomsan A. Pangan dan gizi jilid I. Jakarta: Raja Grafindo Persada; 2002.

22. Kemenkes RI. Petunjuk gizi ibu hamil. Jakarta: Kementerian Kesehatan RI; 2011.

23. Siege-Ritz et al. Frequency of eating during pregnancy and its effect on preterm delivery. Am J Epidemiol. 2001;153(7).

24. Susanti A, Rustono, Asiyah N. Budaya pantang makan, status ekonomi dan pengetahuan zat gizi ibu hamil pada ibu hamil trimester III dengan status gizi. JIKK. 2013;1:1-9.

25. Surasih $\mathrm{H}$. Faktor-faktor yang berhubungan dengan keadaan kurang energi kronis (KEK) pada ibu hamil di Kabupaten Banjarnegara. Institut Pertanian Bogor; 2005.

26. Gunawaty A. Analisis pola konsumsi makan dan status gizi ibu hamil di Kabupaten Dati II Purworejo Propinsi Jawa Tengah. Universitas Gajah Mada; 2000.

27. Milne E, Bailey H, Scott R, Royle J, Bower C, Kirby $M$, et al. Maternal consumption of coffee and tea during pregnancy and risk of childhood ALL: results from an Australian case-control study. Cancer Causes Control. 2011;22:20718. 
28. Ethen M, Ramadhani T, Scheuerle, Canfield M, Wyszynski D, Druschel C, et al. Alcohol consumption by women before and during pregnancy. Matern Child Heal J. 2009;13:27485.

29. Chaffin M, Cohn B, Anglemyer A, Cohen R, Christianson R. Maternal smoking, alcohol, and coffee use during pregnancy and son's risk of testicular cancer. Alcohol 43. 2008;241e245.

30. Torri M. Knowledge and risk perceptions of traditional jamu medicine among urban consumers. Eur J Med Plants 3. 2010;1:2539.

31. Oni $\mathrm{O}$, Tukur. Identifying pregnant women who would adhere to food taboos in a rural community: a community-based study. Afr J Reprod Health. 2012;(16):3.

32. Lee D, Ngai I, Ng M, Lok I, Alexander, Chung T. Antenatal taboos among Chinese women in Hong Kong. Scienedirect Midwifeny. 2009;25:104-13.

33. Alwi Q. Tema budaya yang melatarbelakangi perilaku ibu-ibu penduduk asli dalam pemeliharaan kehamilan dan persalinan di Kabupaten Mimika. Bul Penelit Kesehat. 2007;35(3):137-47.

34. Baumali M. Pemenuhan zat gizi ibu nifas dalam budaya se'i pada masyarakat Suku Timor Dawan di Kecamatan Molo Selatan Kabupaten Timur Tengah Selatan. Universitas Gadjah Mada; 2009.

35. Nadesul H. Makanan sehat untuk ibu hamil. Jakarta: Puspa Swara; 2009.

36. Hartini et al. The importance of eating rice: changing food habits among pregnant Indonesia women during the economic crisis. Soc Sci Med. 2005;61:199-210.

37. Simarmata M. Hubungan pola asupan, ketersediaan pangan, pengetahuan gizi dan status kesehatan dengan kejadian KEK pada ibu hamil di Kabupaten Simulungun. Universitas Sumatera Utara; 2008.

38. Ahmed S, Adams A, Chowdhury A, Bhuiya A. Chronic energy deficiency in women from rural Bangladesh: some socioeconomic determinants. J biosoc Sci. 1998;30:349-58. 